\title{
THE Mitoni TRADition aS SOCIAL, CUlTURAL, AND SPIRITUAL REINFORCEMENT OF JAVANESE SOCIETY
}

\author{
Nana Najmina ${ }^{1 *}$, Eny Kurdarini ${ }^{2}$ \\ ${ }^{1}$ Yogyakarta State University, Yogyakarta, Indonesia, e-mail:nananajmina@gmail.com \\ ${ }^{2}$ Yogyakarta State University, Yogyakarta, Indonesia, e-mail:eny.kusdarini@gmail.com \\ *Correspondence Author
}

\author{
(c) (i) (2) \\ (C)2020 by the authors. Submitted for possible open access publication under the terms and conditions of the Creative Commons \\ Attribution-ShareAlike 4.0 International License-(CC-BY-SA) (https://creativecommons.org/licenses/by-sa/4.0/)

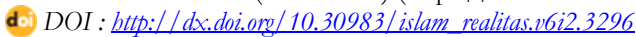

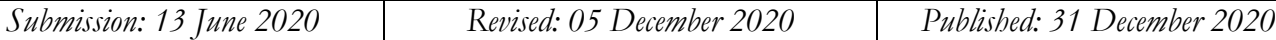

\begin{abstract}
This study examines how the social, cultural and spiritual values of the Mitoni tradition has "strengthened" the social and spiritual culture of the Javanese Muslim community. The Mitoni tradition is one of the best preserved tradition of the Javanese people from generation to generation, especially in Central Java. However, this tradition has received a lot of criticism from conservative religious adherents who accuse it of being a deviant practice. Yet this tradition embodies social, cultural and spiritual values that teach people to live together to create social harmony. This research uses a qualitative descriptive approach. It argues that Mitoni tradition contains irreplaceable cultural-historical values. By carrying out the tradition, the community hopes that someday the young generation can live in security and can embody good moral and personal traits that can then strengthen their social and spiritual bonds with fellow human beings.
\end{abstract}

Keywords: Culture; Java; Mitoni; Society.

\begin{abstract}
Abstrak
Kajian ini bertujuan untuk mengkaji nilai sosial, kultural dan spiritual tradisi Mitoni sebagai "penguatan" sosial kebudayaan spiritual masyarakat Muslim Jawa. Tradisi Mitoni ini merupakan salah satu adat yang sangat dilestarikan oleh masyarakat Jawa khususnya di Jawa Tengah yang dilakukan secara turun-temurun. Hanya saja, tradisi ini banyak mendapatkan kritikan dari aliran keagamaan konservatif yang menuduh sebagai tradisi menyimpang dari ajaran Islam. Padahal semestinya, tradisi mengandung nilai sosial, kultur dan spiritual dalam tradisi ini yang mengajarkan masyarakat untuk hidup bersama untuk menciptakan harmoni sosial. Penelitiaan ini menggunakan kualitatif dengan pendekatan deskriptif. Maka hasil kajian ini bahwa tradisi Mitoni mengandung banyak nilai-nilai bistoris dan kultural. Dengan melaksanakan tradisi mitoni masyarakat berharap kelak anak yang akan labir diberi keselamatan dan dapat menjadi anak yang memiliki kepribadian yang baik serta dapat menjadi suri tauladan, selain itu dengan mengadakan tradisi tersebut secara tidak langsung mereka sudah mempererat tali silaturrahmi antar sesama.
\end{abstract}

Kata Kunci: Budaya; Jawa; Mitoni; Masyarakat.

\section{Background}

The tradition of Mitoni contains deep customary (adat) values for those practice it. For the local community performing it is a means to prove their obedience to the religious and cultural norms of their society. They hope that this will allow their tradition to be continued by their children, thereby maintaining the unique aspects of their regional culture. In the Javanese community, culture is defined as the true inheritance or the legacy of the past. A culture that is well- maintained never happens by accident. Culture gives birth the local identity of a region, and one manifestation of a culture is tradition. Traditional practices are a series of human activities that have been implemented for a long time by successive generations of ancestors. Traditional practice is influenced by the tendency to do something in a certain way, which then becomes a social habit. It is a form of culture that displays tangible activity or action. The Javanese culture is a system that serves as a guide for Javanese people in their lives. Local wisdom in Javanese culture 
functions as a powerful driver of a local community's life. ${ }^{1}$ Traditional practice consists of certain customs that are endemic in a given culture. Traditional practices are often carried out by certain groups of people in the community and is an effort to preserve local identity, maintain safety, and offer guidance in life. $^{2}$

Culture is a way of life is owned jointly by a group of people and passed down from generation to generation. Culture is formed by many elements that are related to each other in a complicated way, such as religion, politics, customs, language, utensils, clothing, buildings, and works of art. Culture is an inseparable part of the human self; as a result, that many people tend to think of it as being inherited genetically. When a person communicates with people of a different culture is able to do so competently, this proves that he has studied that culture. One of the cultural forms of Indonesian culture that contains the value of the sublime is a traditional ceremony called Mitoni. Every ethnic group has traditional practices related to pregnancy, whether in terms of clothing, equipment, accessories and procedures for the implementation of seven months of each area. One of them is the tradition of Mitoni. The implementation of the tradition by the majority of indigenous ethnic Javanese uses a variety of processes that created and define the Javanese community. Thus, it is reasonable if the people uses the ceremony Mitoni during a woman's pregnancy. Customs that are associated with pregnancy convey a specific meaning to life and act as a representation of the tradition.

One of these traditional practices is the Mitoni tradition that takes place during the seventh month of pregnancy. Mitoni is the Javanese tradition that takes place during a woman's seventh month of pregnancy. Pregnancy, which in the Javanese language is called mbobot/meteng, receives serious attention from the Javanese people. The Mitoni tradition or tujub bulanan ("seventh-month pregnancy") is preserved from generation to generation in the Javanese community. Mitoni is a form of Javanese culture that is passed down from generation to generation. Thus, it is now considered as a sacred tradition. Culture is deeply meaningful for the community, because culture teaches human beings to live in harmony with nature, while providing guidance on how to interact with each other. This is because language is a vehicle to pass customs from one generation to generation another. Human beings have the ability of establishing cultural traditions in order to create an understanding of reality that is expressed symbolically, and then passing it on to future generations.

Mitoni is a ritual specifically intended for women's well-being and salvation. It is held to offer prayers for the pregnant mother and her child that they be given safety until the child is born. The Mitoni tradition is a major custom that follows-up the ceremony of marriage. Another Javanese ritual that carries local wisdom is the birthing ritual. Some of the related ritual traditions are brokohan, or the ceremony after the baby is born, sepasaran (five days), selapanan (thirty-five days), telunglapan (three months and fifteen days), mitoni (seven months) and ngetahuni. These traditional practices are part of the religious habit that has been passed down in Javanese socio-cultural community. ${ }^{3}$ Mitoni is a ceremony performed
${ }^{1}$ Kundharu Saddhono and Dewi Pramestuti, 'Study of Religious Values Based on Local Wisdom', El Harakah, 20 (2018), 15-33.

2 M. Rifa'i, 'Etnografi Komunikasi Ritual Tingkeban Neloni dan Mitoni', Ettisal Jurnal of Communication, 2.1 (2017), 27-40.
3 Ulin Nuha, 'Tradisi Ritual Buka Luwur: Sebuah Media Nilai-Nilai Islam dan Sosial Masyarakat Kudus', Smart, $\quad 2.01 \quad$ (2016), $\quad 55$ <https://doi.org/10.18784/smart.v2i01.298>. 
in the seventh month of pregnancy in Javanese society. ${ }^{4}$

Some sources states the Mitoni ceremony originated from life crises. Human life has several stages, namely: birth, childhood, adulthood, marriage, and death. The transition from one stage to the next one is often a critical period. In their lifetime, human beings experience many crises that are often frightening.

No matter how happy someone's life is, the possibilities of crisis occurring in his life is always a haunting presence. The crisis may be in the form of disaster, illness, and death. Disasters cannot be controlled or regulated by being beings despite their intelligence, power, or wealth.

In coping with life crises, people need to do something to strengthen their faith and themselves. Therefore, some Javanese strongly believe that the Mitoni ceremony can get rid of disasters that can befall the mother and the baby.

Previous studies of the Mitoni ceremony are as follows: a study by Rifa'i examines Mitoni in terms of the communication that occurs in the community ${ }^{5}$; a study by Mustaqim found that the Mitoni ritual performed today has changed in terms of the meaning and the quality of the tradition (Mustaqim, 2017:120). ${ }^{6}$ However, previous studies have been silent on the spiritual values of Mitoni as a social reinforcement. ${ }^{7}$ Therefore, this study explains the spiritual values of the Mitoni tradition and shows how it functions as social reinforcement of Javanese society. In addition, this research is motivated by the threat of social disharmony that is currently threatening Javanese society.

Indonesian society in general often experiences violent conflict. This is due to a lack of public awareness of cultural and religious teachings. ${ }^{8}$ Besides, Javanese society with its various religions is susceptible to conflict and separation. ${ }^{9}$

This study employs a qualitative field research method. The qualitative research method is based on postpositivist perspective that regards social reality as holistically complex, dynamic, and full of meaning. ${ }^{10} \mathrm{By}$ analyzing the traditional ceremonial rituals, this research is carried out using a qualitative descriptive method. It is based on an analysis of the customs that are enacted in the community. These observations are then combined into qualitative data that is based closely on existing conditions.

In principle, the values of mitoni radition teach social equality amid the current influence of conservative religious ideas in Java, which is due to a weakening of people's religious and cultural understanding. In fact, this phenomena of conservatism creates prejudice and suspicion against people of different beliefs. Understanding social, cultural and spiritual values in this tradition should teach people how to live together to create social harmony. The problem discussed in this study is how the Mitoni tradition acts as social, cultural, and spiritual reinforcement in Javanese society.
4 S. M Dagun, Kamus Besar Imu Sosial (Jakarta: Lembaga Pengkajian Kebudayaan Nusantara, 2015), p. 23.

${ }^{5}$ Rifa'i.

${ }^{6}$ Muhamad Mustaqim, 'Pergeseran Tradisi Mitoni: Persinggungan antara Budaya dan Agama', Jurnal $\begin{array}{lll}\text { Penelitian, } & 11.1 & \text { (2017), }\end{array}$ <https://doi.org/10.21043/jupe.v11i1.2016>.

${ }^{7}$ Mustaqim.
${ }^{8}$ Nasri Kurniallah Dan Sri Suharti, 'Pendidikan Islam Berbasis Inklusif dalam Kehidupan Multikultur', Jurnal Penelitian, $10.1 \quad$ (2016), 201-32 <https://doi.org/10.21043/jupe.v10i1.868>.

9 Masduki, 'Toleransi di Masyarakat Plural Berbasis Budaya Lokal (Studi Kasus di Desa Klepu, Kec. Sooko, Kab. Ponorogo)', Sosial Budaya, 4.1 (2017), 14-22.

10 Sugiono, Metode Penelitian Kualitatif untuk Penelitian Yang Bersifat: Eksploratif, Interaktif dan Konstruktif (Bandung: Alfabeta, 2017), p. 23. 


\section{The Process of the Mitoni Tradition}

Cooking

The family cooks a meal that will be brought home by the guests. The cooking activities are carried out in the morning at the residence of the family that is holding the celebration. The dishes include ingkung (a whole fried chicken), nasi tumpeng (cone-shaped white rice), urap (seven types of vegetables that are boiled and mixed with herbs), boiled market snacks (cassava, sweet potatoes, taro, pumpkin, banana, beans, and oranges), and rujak (Indonesian traditional fruit salad). The parties involved in this activity are the families who carry out the Mitoni tradition, relatives, and neighbors.

\section{Inviting the Guest}

Inviting guests is an activity carried out by family members who ask relatives and neighbors to come to the ritual. This activity can be done after cooking or a day before.

\section{Waiting for the Guest}

Before the guests start arriving, the family gets ready. The family changes to neat clothing, serves food, and puts on the equipment of the ceremony in the designated places such as in the bathroom and outside the bathroom.

\section{The Procedure of Mitoni Tradition in Javanese Society}

The informant also explained the preparations that must be done at the Mitoni event. One person should prepare the water that will be used for spraying. The water is taken from seven wells. These can be anyone's well as long as the owner gives permission. Once the water is collected, all you have to do is look for telon flowers. What flowers are important three kinds of flowers. Then look for two large coconuts to sit on and two ivory coconuts to be crushed later. When you get all of them, one must buy seven batik clothing that will be worn when carrying the child after birth. ${ }^{11}$ Preparation is done the day before the event. Prepare the water that will be used to spray (i.e. water taken from seven wells). Take the water one well a bailer, up to seven times one the well from the well itself. The water from seven of these wells as a process of seven months as a sign that this event for seven monthly. If the water is already there just have to search for the flowers of three way. Flowers as a symbol of beauty and fragrance have the meaning to give the fragrance for the expectant mother and family. The symbol of the seven months is anything that used to be seven or odd, including the interest used must be seven of flowers from three different directions. The number intended must be odd. One must purchase seven new batik fabrics that will be used for carrying the baby after birth. The village community of Layansari believe that if a pregnant woman does not carry out the Mitoni ritual then bad things are going happen, like a difficult labor that could cause death to either the mother of child. This whole process is meant to maintain the health of the mother and child throughout pregnancy.

Further, the requirements for holding Mitoni ceremony are described follows: (a) The ceremony shall not be held at random day. Rather, a specific date that is considered auspicious for holding a Mitoni ceremony is chosen. According to serat tatacara, a good day for the Mitoni ceremony is Wednesday (or Tuesday afternoon and evening) or Saturday (or Friday afternoon and evening). The ritual should be held before the full moon; (b) The place to hold the ceremony is usually in front of pasren, which is the senthong tengah. Pasren is viewed by many farmers as a place for the worship of Devi Sri (Devi Padi), the goddess of rice. Most people nowadays no longer have senthon. Thus, the Mitoni ceremony is held in

\footnotetext{
${ }^{11}$ Sutiyah, (Women in community) Interview \{Monday, 07 June 2019\}
} 
the family room, or a large room to hold a ceremony, or even in the home yard.

According to Fitoh, the ceremony is performed by a shaman or the oldest family member. ${ }^{12}$ The presence of a shaman is ceremonial to prepare and carry out the ceremony. A series of ceremony for the tingkeban ritual is as follows; First, Making rijak. In Javanese tradition, rujak is made by the prospective mother. If the rujak is salty, usually the baby is female. If it is not salty, usually the baby is male. Due to medical technology advancement, prospective parents can use ultrasound to see the baby's gender;

Second, Siraman of the prospective mother. Siraman ceremony is carried out by seven elders or family members. The informant also said that "before the water is poured over, the water is given petals of flowers and is sanctified by prayer. The prayer is made to God, asking for the purification the mother and baby. ${ }^{13}$ It aim asks for blessings to keep the baby physically and spiritually pure. The prospective mother wears seven batik cloths wrapped around her body (kemben). In a sitting position, the pregnant woman is first watered by her husband, then by her parents and other family members. The purpose of this ceremony is to wash away all the dirt and other negative influences. There are things that must be done in the siraman procession. The informant explained that "first, water from the seven wells is $\backslash$ mixed with one's own water. Then the telon flowers are placed in the water and then poured over the pregnant women. Before being poured over, the pregnant woman sits on two coconuts tied together. The goal is to keep the baby's exit wide open so that it will be easy for the baby to come out. ${ }^{14}$
Third, throwing chicken eggs. After siraman, chicken eggs are put into the prospective mother's cloth by the husband through the waist; the eggs are then broken by dropping them. This ceremony is meant to convey the hope that baby will be born smoothly and safely.

Fourth, Pantes-pantes or changing the cloth seven times. The pantes-pantes ceremony is a ceremony to change seven wraps of regular cloths with seven types of batik cloths. The motifs of the long cloth and kemben convey the wish that the baby will get be blessed with good things. The function and purpose of the clothing in Mitoni are related to hopes for the safety of the labor process. ${ }^{15}$ The first to the sixth long cloths and kebaya show luxury and greatness. The female guests should answer: "dereng pante" ("it does not suit!") when they are asked if the clothing is suitable to the prospective mother. The last seventh cloth is in the form of a simple lasem motif. The female guests will now answer "pantes" ("it is wellsuited!') when they are asked the same question. This ritual symbolizes the prayer that the baby will be a rich person. The number seven symbolizes the seven holes of the body (two eyes, two ears, one nose, one mouth, and one genitalia), all of which should be pure and clean. There is another understanding of the number seven, which is keratabasa. The number seven in Javanese languade is pitu, from the word pitu-lungan (means help). Different motifs of the long cloth and kemben signify different kinds of good wishes; (1) Sidolubur means that baby will be born as a polite human being with noble character; (2) Sidomukti means that baby will be born as a human who is able to show prestige, who is happy and respected because of his authority; (3) Truntum means that the

\footnotetext{
${ }^{12}$ Nurul. Fitoh, Ritual Tingkeban dalam Perspekif Aqidah Islam (Semarang: Universitas Islam Negeri Walisongo Semarang Press, 2014), p. 23.

13 Sutiyah, (Women in community) Interview \{Monday, 07 June 2019\}
}

\footnotetext{
${ }^{14}$ Sulasih, (Women in community) Interview \{Monday, 07 June 2019\}

15 Nurcahyanti, 'Tafsir Tanda Penggunaan Busana dalam Upacara Adat Mitoni di Puro Mangkunagaran Surakarta, Spada, 3. 2 (2010), 1-20.
} 
baby will take after his parent's nobility; (4) $W$ abyu temuru means that the baby will be born to be a person who is always close to God Almighty and always receive His guidance and protection; (5) Udan riris means that the child can please the people around him; (6) Sidoasib means that the baby will be born as someone who is loved and is loving of others; and, (7) Lasem means that the child is devoted to God Almighty

Fifth, Splitting the ivory coconut. Two ivory coconuts, on which are drawn the figures of Kamajaya and Kamaratih. By drawing these two wayang figures, the hope is that baby would become as handsome as Kamajaya or as beautiful as Kamaratih, as they are god and goddess of true affection. The two ivory coconuts are handed over to the husband by the prospective mother. The prospective father will split the second coconut into two parts with a bendo. This symbolizes the conviction that only God determines the gender of the baby. (f) Selamatan; this ritual takes place in the evening after finishing the earlier processions. Sometimes people complete the ceremony by inviting certain guests, especially kyai or ustadz, (Islamic teachers). Some of the most frequently chosen Surah of the Quran that are recited during the Mitoni ceremony are Yūsuf, Luqmān, Maryam, Yasin, al-Waqi'a, ArRahman, al-Mulk, Taha, and An-Nur. The surahs have meanings that is auspicious for the health and flourishing of the baby. For example, reading surah Yùsuf expresses the wish that the baby will be as kind-hearted and good-looking as prophet Yūsuf (Joseph), while reading surah Maryam expresses the wish that the baby girl will be a virtuous and pious woman like Maryam (Mary).

The dishes served in the Mitoni tradition are also an important part of the ceremony. Eating together expresses gratitude to God for His blessings. Various dishes are served including (a) Tumpeng sapta nugraha, which uses a large tray because it consists of seven cones. One of them is the large cone that is surrounded by six smaller cones. This Tumpeng serves as a symbol of the fetus' age. Eating the cones symbolizes prayers that God will gift the baby seven primacies of life, namely wisdom, advice, sincerity, strength, simplicity, devotion, piety, and sincerity. The cone is cut by the prospective father as a symbol of gratitude that the Mitoni ceremony has been carried out smoothly. The cone is given to the prospective parents. This symbolizes that the father will take good care of his wife and children; (b) Seven types of porridge consisting of jenang procot, bubur candil, bubur mutiara, bubur sunsum, mung bin porridge, black sticky rice porridge, and corn porridge. These symbolize the wishes for a smooth labor; (c) Sticky rice or sevencolor jadah that symbolizes family happiness awaiting the presence of the child; (d) Takir potang is given to the elders to express gratitude for their attendance of the Mitoni ceremony.

The function and purpose of the tradition is usually understood by the people who regularly perform it. According to the informant, anyone offering the ritual must always say thanksgiving to God for providing the mother with seven months of healthy pregnancy prior to the performance of the ritual. Thanksgiving ceremonies like this Mitoni has been around since time immemorial. Thus, it is always carried out when someone is pregnant for seven months. This is almost an obligation, because the local community believe that if you do not do it, something unwanted will happen. ${ }^{16}$

From the description above, the researchers have concluded that the Mitoni tradition is a tradition carried by successive generations to mark the occasion of a mother's seven-month pregnancy with her first child. The Mitoni ceremonies express gratitude to God for giving health to pregnant women and the children in

${ }^{16}$ Sulasih, (Women in community) Interview \{Monday, 07 June 2019\} 
their wombs. They also forms of prayer, requesting safety for mother and child during childbirth.

\section{The Spiritual Values of the Javanese Mitoni Tradition}

The spiritual values of]avanese myth are as follows: Ngruwat Sukerta. Ngruwat Sukerta or throwing bad luck away is the spiritual value of siraman. Ruwatan is a ceremony to free someone who is possessed or disturbed by demons or evil spirits. ${ }^{17}$ The Ruwatan ceremony is believed by the local community to be a shield or weapon to prevent various dangers or disaster. $\mathrm{s}^{18}$ Ruwatan is done to attain inner enlightenment and break the karmic chain of events. ${ }^{19}$ Ngruwat sukerta means purification from any form of defilement attached to the mother and father that could be passed down to the children. Children should be born pure from bad things.

Setiawan explains that the Mitoni ceremony is a form of self-cleansing, both physical and mental. ${ }^{20}$ The mother is first and foremost a caregiver of the baby who is still in the womb. ${ }^{21}$ She can take good care of her child because she has been purified through siraman.

Preparation or Cecawis are the spiritual values found in the stages of changing cloths. This means that parents would be able to have psychological strength and material means to deal with childbirth. When having children, parents will experience ups and downs that are symbolized by the seven different motifs of the cloths.
The stage of changing clothes also has the spiritual value of responsibility or justice. The hope is that the family would be self-sufficient, which in Javanese is sembada. Literally, the word sembada means sufficient, complete, and strong. Responsible people can meet their own needs. $^{22}$

Panampi or acceptance is the spiritual value of women undergoing labor. The hope is that parents are able to accept the birth of their children whatever the gender. This attitude expresses nrima or "acceptance". This is in accordance with the Javanese advice: "ndarbeni ati segara" or to have a heart as wide as the ocean. $^{23}$

Wilujeng or "the saved" is a spiritual value in kenduri. A pregnant woman prays for her and her baby's safety during labor. The word wilujeng can also mean warm words with a smooth tone and conveys congratulations. ${ }^{24}$ Geertz, qas uoted by Wahidah, identified the slametan as (1) the "core ritual" of Javanese culture; (2) animism ceremony that aims to strengthen social integration; and (3) as the main ceremony in a village (Wahidah, 2015:210). ${ }^{25}$ The Javanese word for tabniah is selamet. Selamet has the meaning of safety and security. ${ }^{26}$ Selametan aims to strengthen social integration. ${ }^{27}$

Ngruwat Bumi. Siraman also has the spiritual value of preserving the universe. Water used is recommended to be taken from seven different wells (tuk pitu). Human beings should maintain the water wells in each village so it does not dry up. The spiritual value of preserving nature is
17 M. A Syuropati, Kamus Pintar Kawruh Jawa Daftar Kata, Nama dan Istilab Penting dalam Bahasa, Sastra dan Budaya Jawa (Yogyakarta: In Azna Books, 2015), p. 123.

${ }^{18}$ Hidayatul Wahidah, 'The Ritual and Mythology of Ruwatan in Mojokerto', Religió: Jurnal Studi Agama-Agama, $5.2(2015)<$ https://doi.org/10.15642/religio.v5i2.573>.

$19 \mathrm{Ki}$ Sondong Mandali, Bawarasa Kawrub Kejawen Ngelmu Urip (Semarang: Adicipta Karya Nusa, 2010), p. 34.

${ }^{20}$ E. Setiawan, 'Nilai Religious Tradisi Mitoni dalam Perspektif Budaya Bangsa Secara Islami', Al-Adalah, 18.1 (2015), 39-52.
21 I. B Santosa, Spiritualisme Jawa Sejarah, Laku dan Intisari Ajaran (Yogyakarta: Memayu Publishing, 2012), p. 65.

22 Syuropati.

${ }^{23} \mathrm{G} \&$ Wulandari Sumodiningrat, Pitutur Lubur Budaya Jawa (Yogyakarta: Narasi, 2014), p. 34.

24 Syuropati.

25 Wahidah.

${ }^{26}$ Syuropati.

27 Wahidah. 
the Javanese people's effort to preserve the universe.

Pitutur. The stages of the Mitoni ceremony have the spiritual value of pitutur or advice. Pitutur is delivered by the father addressing his pregnant daughter and son-in-law. The advice contains guidance to help the child and his sonin-law on how to mentally, physically, and spiritually welcome the baby when he or she is born.

Rukun. Javanese people believe that rukun or harmonious relationship is manifested when people can eat together. In line with Surbono's description, Javanese harmony is associated with prayer and collective eating with members of the local community. ${ }^{28}$ The spiritual value of harmony can be found at the kenduri. Kenduri is a joint dining ceremony that functions as a social, cultural, and spiritual reinforcement for the Javanese people.

Pitulungan. Human always need other people in their lives. This is also the view of Javanese life. The number seven in Javanese is pitu, which means pitulungan or help. This is why in Mitoni salvation is symbolized by the number seven. These values may be used by religious leaders in fostering social harmony.

This value serves as the positive social energy uniting Javanese society. In the religious practice, there is alms. Alms itself is to share one's good fortune with relatives and close neighbors. It is believed that gifts, blessings, and glory are given only to strengthen relationships. The value of this tradition is to encourage the husband and wife to be close to God and pray for the health and safety of mother and child. ${ }^{29}$
Another purpose of this tradition is the teamwork it fosters between neighbors and relatives, especially in the cooking phase. This collective work is meant to ease the work of the host who has to cook a lot of food for the ceremony, such as preparing the porridge, making the snacks, and wrapping dawet.

There is also social value om waiting for the event. Guests would gather and interact with each other. This can strengthen the relationship between relatives and neighbors. After the guests are gathered, the host gives the guests food and drinks and gives an opening speech, before handing over the ceremony to the ulama (elderly scholars) while stating the purpose of the selamatan. This shows mutual respect between the host and the guests. After the selamatan is over, the host thanks the guests and prays for the prospective mother and baby. More food and side dishes will be prepared for the guests to bring home. The aim is to strengthen the relationship between neighbors and families. Traditions must be preserved and maintained by the Indonesian people. The existence of regional national cultures can be passed on to future generations and pplied in various aspects of life. ${ }^{30}$

The Mitoni tradition is the local wisdom of the Javanese people and is a manifestation of their gratitude to God. The stages of the ritual have many philosophical meanings First, siraman, which means purification of the mother's inner and outer body, is conducted in order that bad character of the parents will not be passed on to the child. The husband and wife will change clothes using seven different motifs, choosing the motifs that symbolize certain good traits of character. The brojolan
28 Wahyu Surbono, 'Bentuk dan Makna Simbolik Tembang dalam Konteks Upacara Rebo Pungkasan Kembul Sewu Dulur', Jurnal Pustaka Budaya, 5.2 (2018), 42-51 <https://doi.org/10.31849/pb.v5i2.1577>.

${ }^{29}$ Khaerani Khaerani, Alfiandra Alfiandra, and Emil El Faisal, 'Analisis Nilai-Nilai dalam Tradisi Tingkeban Pada Masyarakat Jawa di Desa Cendana Kecamatan Muara Sugihan Kabupaten Banyuasin', Bhineka Tunggal
Ika: Kajian Teori dan Praktik Pendidikan PKn, 6.1 (2019), 64-82 <https://doi.org/10.36706/jbti.v6i1.7923>.

30 Anisa; Mulyana, Asep; Utami and Itaristanti, 'Peran Tradisi Seren Taun dalam Upaya Meningkatkan Pewarisan Nilai-Nilai Sosial dan Budaya di Kalangan Remaja Kelurahan Cigugur Kecamatan Cigugur Kabupaten Kuningan', Perspektif, V.1 (2016), 99-113. 
stage is then followed by inserting a pair of ivory coconuts with the depictions of the wayang characters of Kamajaya and Kamaratih. This expresses the hope that the child is beautiful and behaves well like the wayang characters. Finally, the prayer, which is a joint prayer led by community leaders and attended by the family members and the local community, asking for the safety of the mother and baby until delivery. In the tradition of Mitoni, prayers for safety for the mother and the child is the dominant rutual. This is why the community is very enthusiastic with this tradition, since it contains long-cherished values. Many of the rituals involved are honored by the Javanese people, such as taking water from seven wells symbolizing seven months. Before this ritual starts, the husband of the expecting mother will take the water from the seven wells that are used for this purpose. The water that comes from the seven wells symbolizes the seven months that has passed since conception. This ritual has been done since time immemorial because people believe in it. Then "telon" or flowers will be mixed with the water before it is poured over the mother. The flower and its fragrance in the water is intended to make sure that the person receiving them will be subject to bad experiences.

The function the Mitoni ritual in all its stages and complexity is to offer prayer to God to grant health and safety to the mother and her children until birth. The value and meaning of the ritual have deep impact on the society that still believes in traditional custom. All human beings whatever the circumstance should be thankful to what is given By God. The Mitoni tradition should also be done with humility and an earnest sincere heart. Only then will the prayers be answered.

It is important for this tradition to continue to be carried out by local communities. Hereditary practices such as this is a form of intercultural communication, because the culture of every generation is different than the one before. However, nowdays the Mitoni tradition is being lost in the midst of an increasingly modern world.

\section{Conclusion}

The traditional Javanese ritual of celebrating the seventh month of pregnancy (tingkeban/mitoni) is a part of the Javanese cultural practices that has deep philosophical meanings in life. In addition, the tradition mitoni is also a cultural tradition that acts as form of prayer requesting health and safety for the pregnant woman. This request must come from a sincere heart. The function of this ceremony is to remain grateful for what the Lord has given. From various of actions and rituals of tingkeban/mitoni, it seems that the Javanese people's wish for salvation is contained in cultural practices. This tradition is a combination of good teachings from Hinduism, Kejawen, and Islam. It is in accordance with the values taught in Islam, i.e., requesting the Creator for safety and happiness. In this tradition, there are several philosophical values that are taught. First, preserving the traditions in asking blessings from ancestors. In the principles of Islamic jurisprudence (usul al-figh), this is known as "almubafarhab" or "ala qadim ash-shalih wal abdzu bil jadidi al-ashlib" (perpetuating good and old traditions and adopting new and better traditions). Second, maintaining a balance between harmony, happiness, and safety (slamet, ora ono apa-apa). Third, the nature of the Javanese people who think associatively. Fourth, the process of self-cleansing (tazkiyatun nafsi) when asking God for blessings. Fifth, it serves as a symbol of silaturabmi, or social solidarity. These values act as cultural reinforcement for the Javanese people. This is because these spiritual values are widely accepted by society. The religious and traditional leaders implement the cultural approach as social, cultural, and spiritual reinforcement. carrying out the Mitoni 
tradition is also proof that the local community is still obedient to the norms that exist in society, both religious and social norms. By carrying out the tradition, citizens hope that someday the child will acquire a good personality and can be a role model like prophet Yusuf and prophet Muhammad peace be upon the, or the mother of Jesus, Maryam. By carrying out the tradition of Mitoni, the child is hoped wo have a humble attitude, both in the presence of God and in the presence of each other. Those who carry out the tradition of the Mitoni will be aware that in this life, one will always require the aid of God and any other human beings. In addition to this, the tradition of Mitoni can also maintain social solidarity and strengthen social and spiritual bonds in the community. The ritual brings neighbors and relatives together in the home of the host, a setting that will strengthen their bonds. Furthermore, gratitude to God is collectively given by conducting a joint prayer. From the results of this study, it is expected that the younger Javanese people would be able to preserve Kejawen philosophy as articulated in the Mitoni ceremony. Traditional practices must be preserved and maintained in Indonesian society. Doing this requires the preservation of regional cultures and studying it in depth. This is done in order to pass the regional and national cultural traits to the future generations, making sure that that wisdom contained in them are applied in the various aspects of life.

\section{References}

Books

Achmad, S. W, Filsafat Jawa: Menguak Filosofi, Ajaran dan Laku Hidup Lelubur Jawa (Yogyakarta: Araska, 2017)

Dagun, S. M, Kamus Besar Ilmu Sosial (Jakarta: Lembaga Pengkajian Kebudayaan Nusantara, 2015)

EM Setiadi, KA Hakam, R Effendi, Ilmu Sosial dan Budaya Dasar (Yogyakarta: Memayu
Publishing, 2011)

Fitoh, Nurul., 'Ritual Tingkeban dalam Perspekif Aqidah Islam' (Universitas Islam Negeri Walisong Semarang, 2014)

Mandali, Ki Sondong, Bawarasa Kawrub Kejawen Ngelmu Urip (Semarang: Adicipta Karya Nusa, 2010)

Murniatmo, Gatot, Khazanah Budaya Lokal (Yogyakarta: Adicipta Karya Nusa, 2000)

Nasir, Muhammad Fauzan, Pembacaan Tujuh Surat Piliban Al-Quran dalam Tradisi Mitoni' Jurusan Ilmu Al-Quran Dan Tafsir IAIN Surakarta, 2016)

Santosa, I. B, Spiritualisme Jawa Sejarah, Laku dan Intisari Ajaran (Yogyakarta: Memayu Publishing, 2012)

Sugiono, Metode Penelitian Kualitatif Untuk Penelitian Yang Bersifat: Eksploratif, Interaktif dan Konstruktif (Bandung: Alfabeta, 2017)

Sumodiningrat, G \& Wulandari, Pitutur Lubur Budaya Jawa (Yogyakarta: Narasi, 2014)

Syarbaini, Syahrial, Pendidikan Pancasila (Bogor: Ghalia Indonesia, 2014)

Syuropati, M. A, Kamus Pintar Kawruh Jawa Daftar Kata, Nama dan Istilah Penting dalam Babasa, Sastra dan Budaya Jawa (Yogyakarta: In Azna Books, 2015)

Yana, M. H, Falsafah dan Pandangan Hidup Orang Jawa (Yogyakarta: Absolut, 2010)

\section{Journals}

Anshori, Mohammad dan Muhamad Mustaqim, 'Peran Jam ' Iyyah Ijtima' Iyyah dalam Pembentukan Tradisi. Jurnal Penelitian 8.1 (2014), 179-200

Basyari, Iin. W, Nilai-Nilai Kearifan Lokal (Lokal Wisdom) Tradisi Memitu Pada Mayarakat Cirebon (Studi Masyarakat Desa Setupatok Kecamatan Mundu)', Edunomic, 2.1 (2014), 1-55

Dan Sri Suharti, Nasri Kurniallah, 'Pendidikan Islam Berbasis Inklusif dalam Kehidupan Multikultur', Jurnal Penelitian, 10.1 (2016), 201-32 $<$ https://doi.org/10.21043/jupe.v10i1.86 $8>$ 
Khaerani, Khaerani, Alfiandra Alfiandra, and Emil El Faisal, 'Analisis Nilai-Nilai dalam Tradisi Tingkeban Pada Masyarakat Jawa di Desa Cendana Kecamatan Muara Sugihan Kabupaten Banyuasin', Bhineka Tunggal Ika: Kajian Teori dan Praktik. Pendidikan PKn, 6.1 (2019), 64-82 <https://doi.org/10.36706/jbti.v6i1.7923 $>$

Machmudah, Umi, 'Budaya Mitoni : Analisis Nilai-Nilai Islam dalam Membangun', Dinamika, 7. 2 (2012), 185-98

Nurcahyanti, Desy, 'Tafsir Tanda Penggunaan Busana dalam Upacara Adat Mitoni di Puro Mangkunagaran Surakarta', Spada 3.2 (2010), 1-20

Masduki, 'Toleransi di Masyarakat Plural Berbasis Budaya Lokal (Studi Kasus di Desa Klepu, Kec. Sooko, Kab. Ponorogo)', Sosial Budaya, 4.1 (2017), 14 22

Mulyana, Asep; Utami, Anisa; and Itaristanti, 'Peran Tradisi Seren Taun dalam Upaya Meningkatkan Pewarisan Nilai-Nilai Sosial dan Budaya di Kalangan Remaja Kelurahan Cigugur Kecamatan Cigugur Kabupaten Kuningan', Perspektif, V.1 (2016), 99-11
Mustaqim, Muhamad, 'Pergeseran Tradisi Mitoni: Persinggungan Antara Budaya dan Agama', Jurnal Penelitian, 11.1 (2017), 119 <https://doi.org/10.21043/jupe.v11i1.20 16>

Nuha, Ulin, 'Tradisi Ritual Buka Luwur: Sebuah Media Nilai-Nilai Islam dan Sosial Masyarakat Kudus', Smart, 2.01 (2016), 55 $<$ https://doi.org/10.18784/smart.v2i01.2 $98>$

Rifa'i, M., 'Etnografi Komunikasi Ritual Tingkeban Neloni dan Mitoni', Ettisal Jurnal of Communication, 2.1 (2017), 27-40

Saddhono, Kundharu, and Dewi Pramestuti, 'Study of Religious Values Based on Local Wisdom', El Harakah, 20 (2018), 15-33

Setiawan, E., 'Nilai Religious Tradisi Mitoni dalam Perspektif Budaya Bangsa Secara Islami', Al-Adalah, 18.1 (2015), 39-52

Surbono, Wahyu, 'Bentuk dan Makna Simbolik Tembang dalam Konteks Upacara Rebo Pungkasan Kembul Sewu Dulur', Jurnal Pustaka Budaya, 5.2 (2018), 42-51 $<$ https://doi.org/10.31849/pb.v5i2.1577 $>$

Wahidah, Hidayatul, 'The Ritual and Mythology of Ruwatan in Mojokerto', Religio: Jurnal Studi Agama-Agama, $5.2 \quad$ (2015) $<$ https://doi.org/10.15642/religio.v5i2.5 $73>$ 